\title{
Appearance of Hormone-sensitive Adenylate Cyclase in the Developing Human Heart
}

\author{
GENE C. PALMER ${ }^{(35)}$ AND WILLIAM G. DAIL, JR. \\ WITH THE TECHNICAL ASSISTANCE OF HALBERT R. SCOTT \\ Departments of Pharmacology and Anatomy, The University of New Mexico School of Medicine, \\ Albuquerque, New Mexico, USA
}

\begin{abstract}
Extract
Highly significant $(P<0.0025)$ increases in adenylate cyclase activity were seen at all fetal age periods $(5-17$ weeks) whenever sodium fluoride $(5-10 \mathrm{mM})$ was added to the enzyme prepared from human myocardium. Norepinephrine (NE) at $10^{-4} \mathrm{M}$ significantly elevated adenylate cyclase activity commencing at $6-7$ weeks $(P<0.01)$. Beginning at $8-9$ fetal weeks, glucagon $\left(6 \times 10^{-6} \mathrm{M}\right)$ effectively activated adenylate cyclase. Other hormonal agents, namely, histamine, epinephrine, and isoproterenol at $10^{-4} \mathrm{M}$, demonstrated an ability to activate the enzyme $(P<0.025)$ by as early as $6-7$ weeks and continued to act in this manner throughout the remainder of the developmental periods investigated. The $\alpha$ blocker, phentolamine, appeared to have little effect on the enzyme in the presence of NE. The $\beta$ blocking agent, propranolol, significantly inhibited $(P<0.025)$ the stimulation of adenylate cyclase by NE throughout the 8-15 fetal week periods.
\end{abstract}

\section{Speculation}

The catalytic (fluoride-sensitive) moiety of adenylate cyclase appears to be present in human fetal myocardium throughout all stages of development. However, the hormonally sensitive receptor components of the enzyme, namely, the catecholamine- and glucagon-sensitive receptors, appear by the 6 th -7 th and 8 th -9 th fetal weeks, respectively. Moreover, the catecholamine receptor is most likely of the $\beta$ type. Likewise, histamine is capable of activating myocardial adenylate cyclase at an early age. Therefore, it appears that at an early period the human fetal heart may have the capability to respond metabolically to sympathetic influences.

Receptor activation of myocardial adenylate cyclase by hormones (catecholamines, histamine, and glucagon) with concomitant production of adenosine $3^{\prime}, 5^{\prime}$-monophosphate (cAMP) has been linked directly to glycogenolysis and indirectly to positive chronotropic and inotropic effects (12, $14,15,20,21)$. Robison et al. (23) postulated that the enzyme adenylate cyclase existed as two separate components. The catalytic component is readily activated in broken cells by fluoride while the receptor moiety is responsive to rather specific hormonal agents. Moreover, the activation of adenylate cyclase in cardiac tissue by catecholamines, histamine, and glucagon has been associated with actions involving separate receptor sites on the enzyme. In this regard $\beta$-adrenergic blockade antagonizes activation of cardiac ade- nylate cyclase by catecholamines but not stimulation elicited by glucagon or histamine $(12,14,15,20,21)$.

During development of the adenylate cyclase system in the rat and mouse heart, recent evidence indicates that the catecholamine-sensitive component of the enzyme is functionally developed at a considerably earlier age than the glucagon-sensitive moiety $(2,27)$. With regard to fetal human myocardial tissues a preliminary study suggested that adenylate cyclase was present and functionally linked to catecholamine and calcium-induced activation of contractility by as early as 12 weeks of gestational age (3). In another investigation, using the high speed particulate fraction from fetal human hearts, we were only able to demonstrate the appearance of the fluoride-sensitive catalytic component of the enzyme from 7-17 weeks of gestational age (4). Since hormonal receptors are extremely labile in fetal tissues (5), the aim of the present study was to utilize a gentle homogenization procedure in an attempt to localize the appearance of the various hormone-sensitive receptors of adenylate cyclase' in the developing human heart of 5-17 weeks of gestational age.

\section{METHODS}

The human fetal and embryonic hearts used for this study were fortuitously obtained from legal abortions performed by suction curettage. Fetal ages were estimated by correlation of femur length with crown-rump length (6), by the wet weight of the heart (4), and by the stage of limb development according to the data of Streeter (25). For fetuses younger than 9 weeks, the fetal limb development and corresponding weights of the heart were the only available means to determine the age. Tissues were normally obtained within 10 min after disruption of the fetoplacental circulation, placed in cold glycylglycine buffer $\left(2 \mathrm{mM}+1 \mathrm{mM} \mathrm{MgSO}_{4}+0.2 \mathrm{mM}\right.$ EGTA, pH 7.4), and returned to the laboratory: Enzymatic investigations were conducted within $1 \mathrm{hr}$ after obtaining the tissue. Extraneous connective tissue was dissected free and the hearts were blotted and rapidly weighed. The hearts were gently homogenized in a loose fitting glass homogenizer with a Teflon pestle in cold glycylglycine buffer $(1 \mathrm{ml} / 10 \mathrm{mg}$ wet wt) and an aliquot was removed for protein determination (16). The enzymatic assay was conducted on $0.25-\mathrm{ml}$ aliquots from the remainder of the homogenate by measuring the amount of cAMP generated from ATP in the presence or absence of various concentrations of $\mathrm{NaF}$ or hormones. The $0.5-\mathrm{ml}$ incubation mixture consisted of the following constituents at final 
concentrations and volumes: (1) $0.1 \mathrm{ml}$ HEPES buffer (40 $\mathrm{mM}$, pH 7.4), containing $3.3 \mathrm{mM}$ theophylline; (2) $0.25 \mathrm{ml}$ crude enzyme preparation; (3) $0.1 \mathrm{ml}$ mixture containing 2 $\mathrm{mM}$ ATP and $3 \mathrm{mM} \mathrm{MgSO}_{4}$; and (4) depending upon the conditions of the experiment either $0.05 \mathrm{ml}$ control solution (bovine serum albumin, $40 \mu \mathrm{g} / \mathrm{ml}$ ), or various concentrations of $\mathrm{NaF}, \mathrm{NE}$, epinephrine, isoproterenol, histamine, glucagon, phentolamine, and propranolol were included (11). All components of the reaction mixture were mixed at $4^{\circ}$ and the reaction was initiated with the addition of MgATP. Incubations were carried out for $12 \mathrm{~min}$ at $37^{\circ}$ in a Dubnoff metabolic shaker. The reactions were terminated by capping the tubes and boiling the samples in a water bath for $5 \mathrm{~min}$. The samples were then centrifuged at $1,000 \times g$ for $15 \mathrm{~min}$ and $0.2 \mathrm{ml}$ supernatant was removed and added to a tube containing $0.05 \mathrm{ml} 0.25 \mathrm{M}$ sodium acetate $(\mathrm{pH} 4.0)$. The samples were then frozen and subsequently assayed for cAMP by the protein binding method (8). Adenylate cyclase activities were expressed as picomoles cAMP synthesized per milligram protein in $12 \mathrm{~min}$. The Student $t$ test was used to statistically evaluate the data and a $P$ value of less than 0.05 was considered to be significant. An ATP regenerating system was not necessary in the present experiments because the enzyme protein concentration was kept relatively small and sufficient amounts of ATP ( $2 \mathrm{mM}$ ) were used to fully saturate the enzyme $(9-11,26)$. Exact levels of enzyme protein were difficult to control but were kept relatively constant within specific age groups, with the most notable exceptions being the samples taken at 14-17 weeks. A preliminary study using a heart of 12 or 13 weeks of gestational age was conducted in order to obtain a time course of enzymatic activity. Activity was linear from 6-24 min incubation. Since the activity of 12 min was halfway on the linear slope of the curve, this time was selected to determine enzymatic activity at the various stages of myocardial development. Limited amounts of available tissue precluded us from obtaining time course and kinetic studies at the various periods of development.

Histamine, L-norepinephrine, L-epinephrine, and L-isoproterenol (29) were dissolved in bovine serum albumin (29) (40 $\mu \mathrm{g} / \mathrm{ml}$ ). Phentolamine- $\mathrm{HCl}(30)$ and propranolol $\mathrm{HCl}$ (31) were dissolved in water. Insulin-free glucagon (32) was initially dissolved in $0.1 \mathrm{M} \mathrm{HCl}$ and then diluted with water to the final concentrations. All drugs were made up immediately before use and double-distilled water was used routinely for all reagents.

\section{RESULTS}

The wet weights of the human fetal hearts at each developmental age are shown in Table 1 . The weight of the hearts at 5 fetal weeks was only $7 \mathrm{mg}$. Within every 2 -week developmental period thereafter, the heart weights were almost doubled. The fresh cardiac tissues were homogenized in $1 \mathrm{ml}$ buffer $/ 10 \mathrm{mg}$ tissue, wet weight; however, with this criterion it was difficult to keep the levels of enzyme protein constant for each developmental period (Table 1).

The basal adenylate cyclase activities tended to vary but were highest at 5-7 and 14-15 weeks of fetal age (Figs. 1-5). Highly significant $(P<0.0025)$ increases in adenylate cyclase activity were seen at all age periods (5-17 weeks) whenever $\mathrm{NaF}(5-10 \mathrm{mM})$ was added to the incubations. An exception to these observations was in the limited study conducted at 16-17 weeks. Usually the maximum stimulation was achieved with $5 \mathrm{mM} \mathrm{NaF}$ with the $10 \mathrm{mM}$ concentration showing either a slight decreased or increased response. At times these fluoride-induced responses were as great as seven-fold over controls. The lowest concentration of fluoride (1 $\mathrm{mM})$, however, activated the enzyme to a lesser but significant $(P<$ 0.01 ) extent at many of the age periods (Fig. 1). At the 6 th -7 th and 16 th -17 th fetal weeks, in which only 1 or 2
Table 1. Wet weights and amounts of enzyme protein per sample of fetal human hearts from 5-17 weeks of development ${ }^{1}$

\begin{tabular}{crcc}
\hline Gestational age, wk & $\mathrm{n}$ & Wet wt, mg & Protein/sample, $\mu \mathrm{g}$ \\
\hline 5 & 3 & $7 \pm 0.7$ & $30 \pm 6$ \\
$6-7$ & 7 & $19 \pm 1$ & $80 \pm 12$ \\
$8-9$ & 14 & $34 \pm 2$ & $108 \pm 14$ \\
$10-11$ & 10 & $64 \pm 4$ & $133 \pm 12$ \\
$12-13$ & 7 & $118 \pm 11$ & $236 \pm 22$ \\
$14-15$ & 6 & $210 \pm 19$ & $205 \pm 33$ \\
$16-17$ & 2 & $390 \pm 45$ & $360 \pm 60$
\end{tabular}

${ }^{1}$ Values are the mean \pm SEM and the mean \pm range if only two hearts were used. $n$ is the number of observations.

samples were available, fluoride at $1 \mathrm{mM}$ did not activate the enzyme significantly.

Norepinephrine $\left(10^{-4} \mathrm{M}\right)$ elevated adenylate cyclase activity significantly commencing at $6-7$ weeks $(P<0.01)$. Concentrations of $10^{-4}-10^{-5} \mathrm{M}$ enhanced enzymatic activities $(P<$ 0.025 ) consistently throughout the 8 th -15 th weeks of development. At times a concentration of NE at $10^{-6} \mathrm{M}(P<$ 0.05 ) stimulated the enzyme significantly (Fig. 2). At all time periods the maximum activation of adenylate cyclase occurred at $10^{-4} \mathrm{M}$. In Figure 2 at the $16 \mathrm{th}-17$ th week developmental period NE did not appear to activate the enzyme. However, at this age period, only two hearts were used and the catecholamine stimulated the enzyme over the two respective controls. Furthermore, these older myocardial tissues exhibited a wider range in basal enzymatic activity.

Glucagon was ineffective from 5-7 weeks of fetal age and actually tended to inhibit basal enzyme activity at 5 weeks. At 6-7 weeks, glucagon $\left(6 \times 10^{-7} \mathrm{M}\right)$ tended to stimulate adenylate cyclase but these observations were not significant (Fig. 3), especially since only a limited number of samples could be obtained for study at these early time periods. Beginning at 8-9 fetal weeks, glucagon effectively activated adenylate cyclase through 13 weeks of development $(P<$ 0.025). Thereafter, hormonal activation of the enzyme occurred to a lesser extent as noted at the 14 th -15 th week time periods. However, when individual hearts were examined, an evaluation over respective control levels was noted consistently. Occasionally, glucagon at a concentration of $6 X$ $10^{-7} \mathrm{M}$ was more effective than the higher dose at $6 \times 10^{-6}$ M (10-13-fetal week periods). The least enzymatic activation was seen with $6 \times 10^{-\gamma} \mathrm{M}$ glucagon except in the one study conducted at 6-7 weeks. In a few preliminary studies inhibition of adenylate cyclase occurred with larger doses of the hormone $\left(6 \times 10^{-5} \mathrm{M}\right)$.

Other hormonal agents, namely, histamine, epinephrine, and isoproterenol at $10^{-4} \mathrm{M}$, demonstrated an ability to activate the enzyme $(P<0.025)$ by as early as $6-7$ weeks and continued to act in this manner throughout the remainder of the developmental periods investigated. At times in the 6 th -7 th week period, epinephrine was more effective than histamine (Fig. 4). However, only limited experiments could be conducted at this period of cardiac development.

In Figure 5 are depicted the results of adding either $10^{-5} \mathrm{M}$ $\alpha$ - (phentolamine) or $\beta$ - (propranolol) adrenergic blocking agents to the enzyme in the absence or presence of $10^{-4} \mathrm{M}$ NE. Throughout the 6 th -15 th fetal weeks the $\alpha$ blocker appeared to have little effect on the enzyme in the presence of NE. If any action was seen, the $\alpha$ blocker tended to enhance either basal or NE stimulation of adenylate cyclase. An exception was observed in the one observation at 16-17 weeks when phentolamine acted to antagonize the enzyme. In a preliminary study, concentrations of phentolamine at $10^{-4}$ and $10^{-6} \mathrm{M}$ were added to the incubated enzyme at ages $8-13$ weeks. In all cases, the actions were similar to that described 

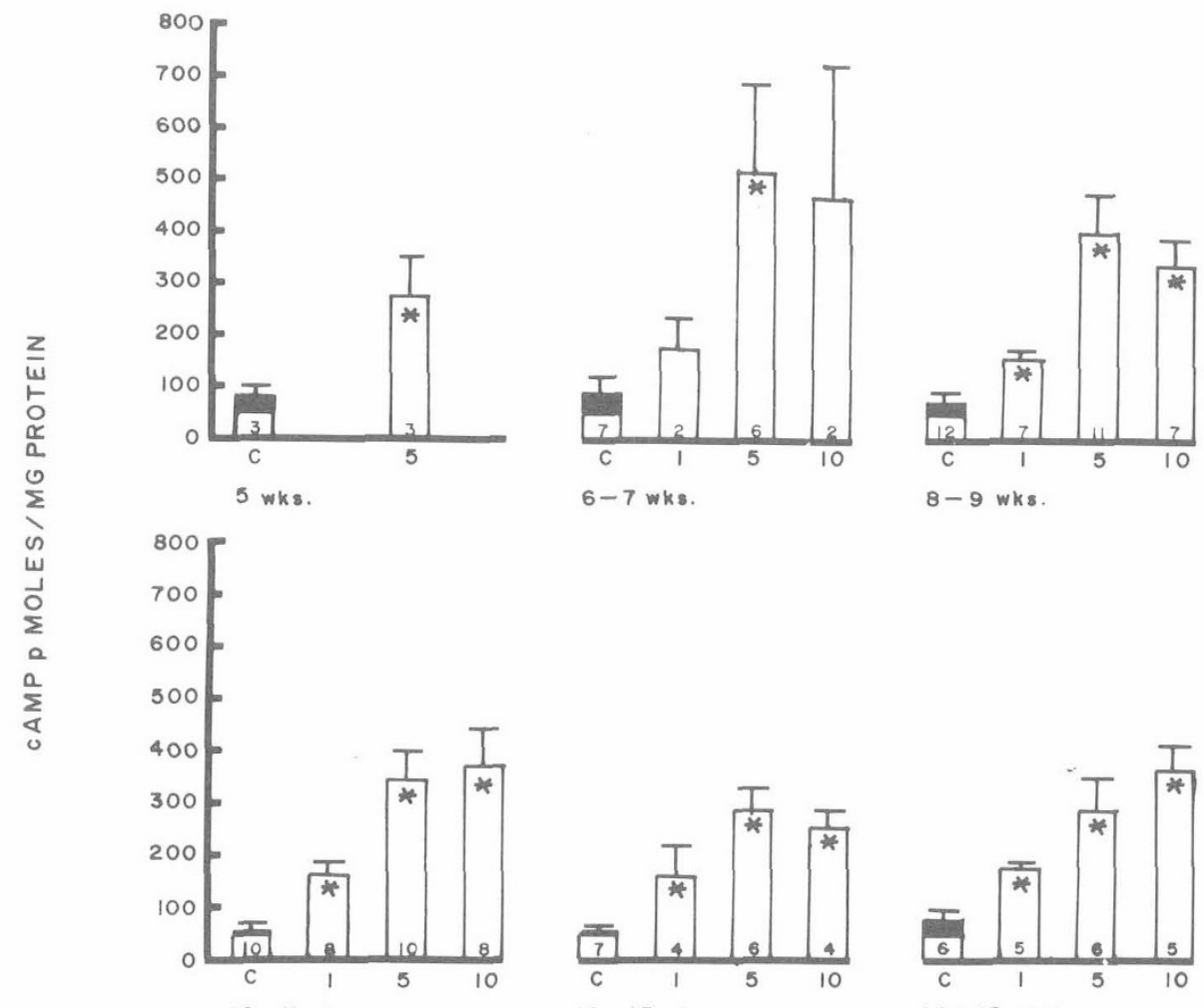

$10-11$ wks.
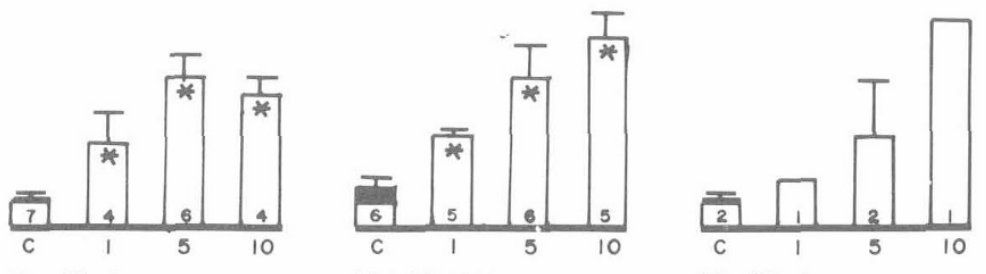

Fig. 1. Activation of adenylate cyclase by fluoride $(1,5$, and $10 \mathrm{mM})$ in the developing human heart. Enzymatic activity is expressed as picomoles adenosine $3^{\prime}, 5^{\prime}$-monophosphate $(C A M P)$ per milligram sample protein after a 12 -min incubation at $37^{\circ}$. For three or more experiments, values are the mean activity \pm SEM; if only two samples were run, values are the average \pm the range between the two samples. The number of individual experiments is noted at the base of each bar graph. *: significant difference from respective control values.
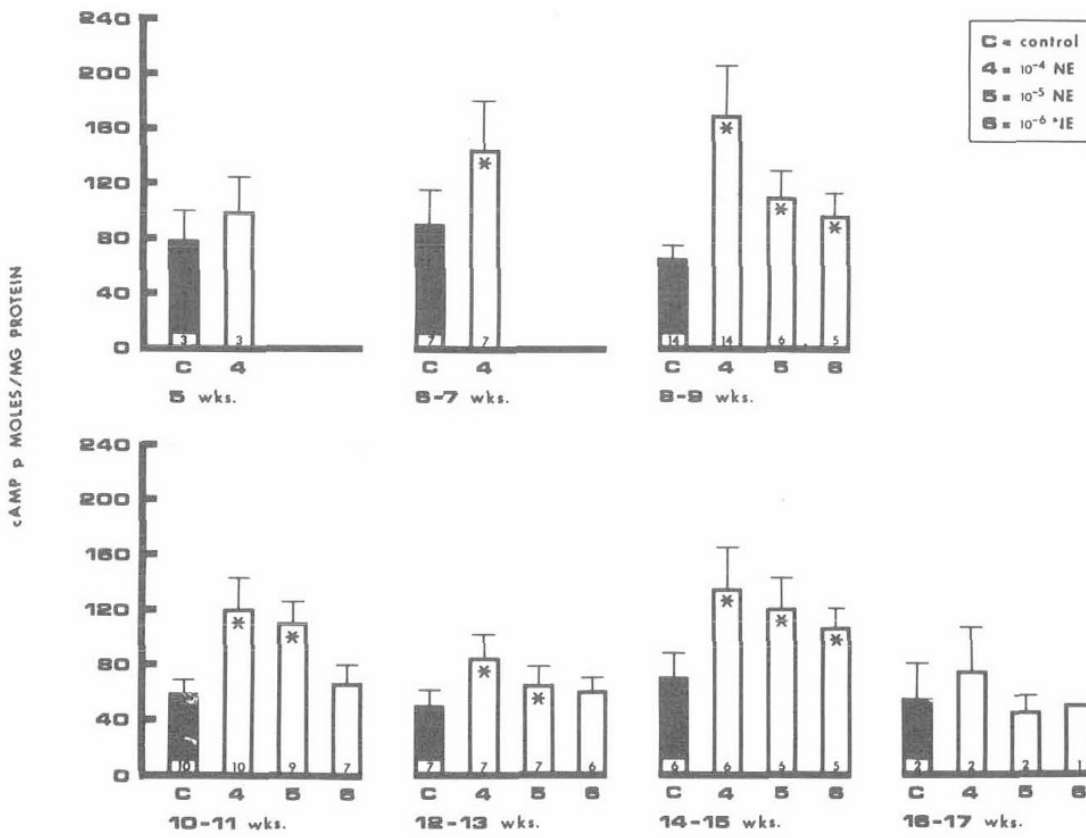

B-g wks.
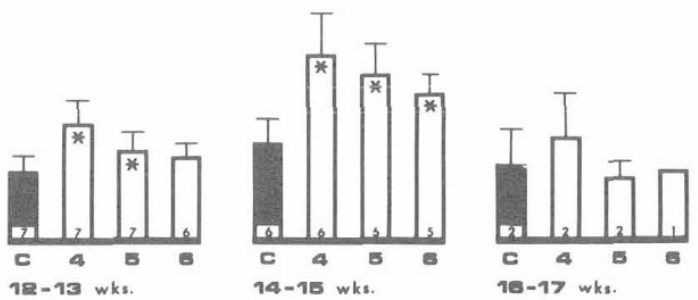

Fig. 2. Activation of adenylate cyclase by L-norepinephrine $\left(10^{-4}-10^{-6} \mathrm{M}\right)$ in the developing human heart. Enzymatic activity is expressed as picomoles adenosine $3^{\prime}, 5^{\prime}$-monophosphate $(c A M P)$ per milligram sample protein after a 12 -min incubation at $37^{\circ}$. For three or more experiments, values are the mean activity \pm SEM; if only two samples were run, values are the average \pm the range between the two samples. The number of individual experiments is noted at the base of each bar graph. *: significant difference from respective control values.

for the $10^{-5} \mathrm{M}$ concentration. The $\beta$-adrenergic blocking agent significantly inhibited $(P<0.025)$ the stimulation of adenylate cyclase by NE throughout the 9 th-15th-week developmental periods. Only two samples were examined at 6-7 and 16-17 weeks and propranolol did not antagonize the
NE-induced activation of adenylate cyclase in these preparations. With regard to an action on basal adenylate cyclase activities, propranolol at times acted to either inhibit or enhance the enzyme. None of these observations were however, significant. In preliminary studies (8-15 weeks) 

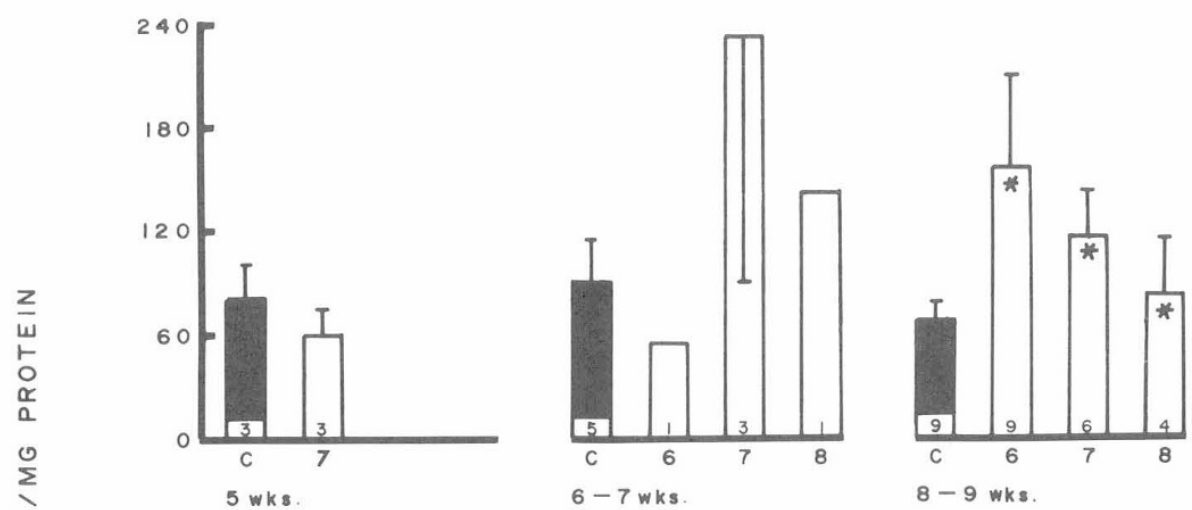

$C=$ control $6=6 \times 10^{-6} \mathrm{M}$ $7.6 \times 10^{-7} \mathrm{M}$ $7=6 \times 10^{-7} \mathrm{M}$
$8=6 \times 10^{-8} \mathrm{M}$ Glucagon

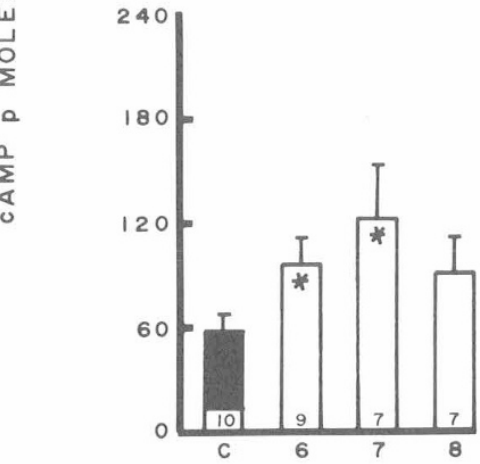

$10-11 \mathrm{wks}$
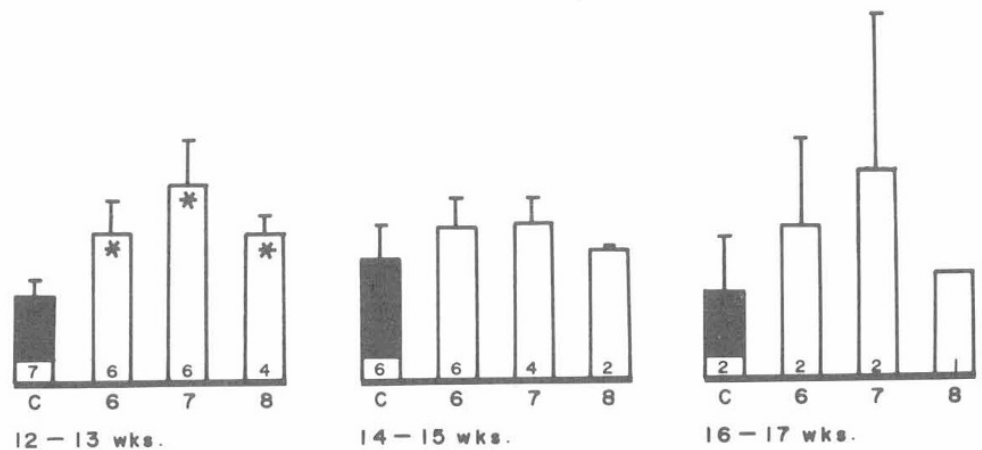

Fig. 3. Activation of adenylate cyclase by glucagon $\left(6 \times 10^{-6}, 6 \times 10^{-7}\right.$, and $\left.6 \times 10^{-8} \mathrm{M}\right)$ in the developing human heart. Enzymatic activity is expressed as picomoles adenosine $3^{\prime}, 5^{\prime}$-monophosphate $(c A M P)$ per sample protein after a 12 -min incubation at $37^{\circ}$. For three or more experiments, values are the mean activity \pm SEM; if only two samples were run, values are the average \pm the range between the two samples. The number of individual experiments is noted at the base of each bar graph. *: significant difference from respective control values.
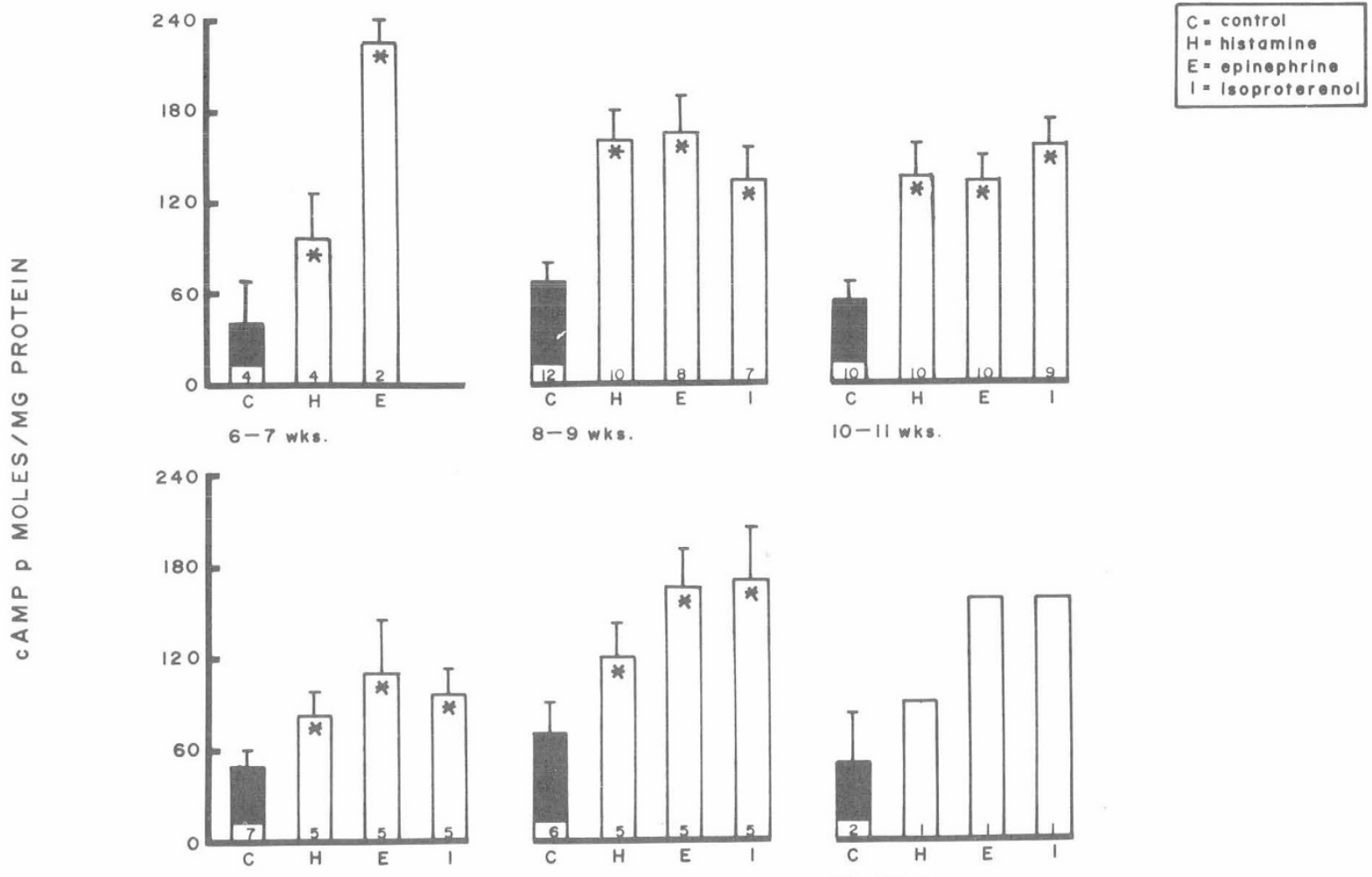

$12-13 \mathrm{wks}$.

$14-15 \mathrm{wks}$.

$16-17 \mathrm{wks}$

Fig. 4. Activation of adenylate cyclase by either histamine, L-epinephrine, or L-isoproterenol $\left(10^{-4} \mathrm{M}\right)$ in the developing human heart. Enzymatic activity is expressed as picomoles adenosine $3^{\prime}, 5^{\prime}$-monophosphate per milligram sample protein after a 12 -min incubation at $37^{\circ}$. For three or more experiments, values are the mean activity \pm SEM; if only two samples were run, values are the average \pm the range between the two samples. The number of individual experiments is noted at the base of each bar graph. *: significant difference from respective control values. 


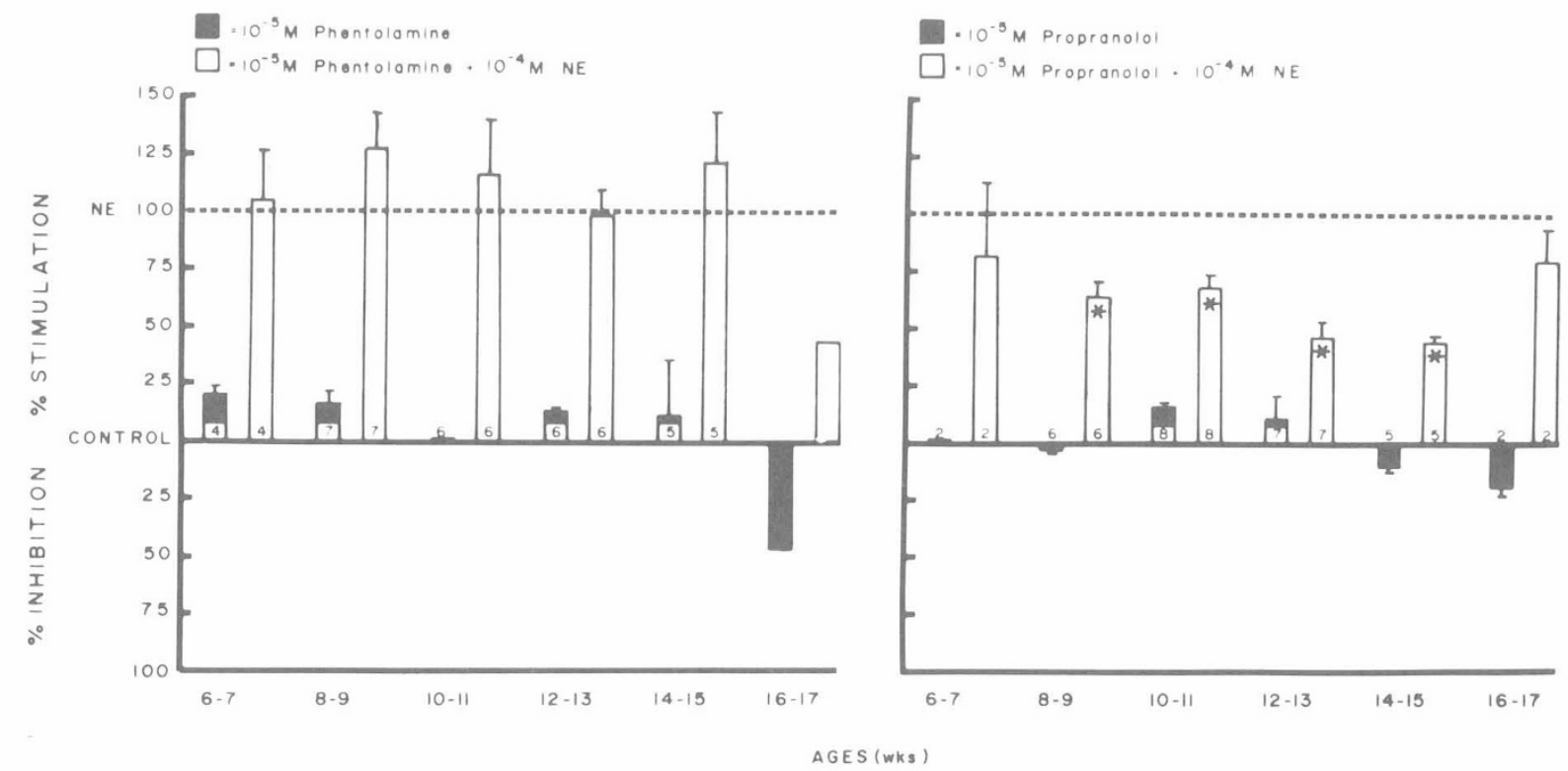

Fig. 5. Effect of $\alpha$ - (phentolamine) and $\beta$ - (propranolol) adrenergic blocking agents on either control or norepinephrine (NE) stimulation of adenylate cyclase in the developing human heart. Either phentolamine or propranolol $\left(10^{-5} \mathrm{M}\right)$ were added to homogenates of fetal myocardium and incubated for $12 \mathrm{~min}$ at $37^{\circ}$ in the presence or absence of NE $\left(10^{-4} \mathrm{M}\right)$. The values in the darkened bars represent the mean percentage of inhibition or activation of respective basal control enzyme activities. The open bars represent the mean percentage of inhibition or activation of respective NE-induced activation of adenylate cyclase. For three or more experiments, values are the mean \pm SEM; if only two samples were run, values are the average \pm range between the two samples. The number of individual experiments is noted at the base of each bar graph.*: significant inhibition by propranolol of the activation of adenylate cyclase by NE.

concentrations of $10^{-6} \mathrm{M}$ propranolol were less effective in their ability to antagonize adenylate cyclase in the presence of NE. Furthermore, in these experiments propranolol at $10^{-4} \mathrm{M}$ exhibited a greater antagonism of the catecholamine-induced activation of the enzyme.

\section{DISCUSSION}

In an earlier communication using an adenylate cyclase preparation derived from the high speed particulate fraction of fetal human hearts we were unable to demonstrate an activation of adenylate cyclase by hormones (4). Moreover, Friedman et al. (5) showed that fetal myocardial receptors that were sensitive to hormones were extremely labile to any mechanical disruption. Partial purification of cellular membranes from fetal lamb heart resulted in diminished activation of adenylate cyclase by glucagon. In these experiments enzymatic activation could only be observed in the total homogenate. With regard to these findings we were, in the present study, able to demonstrate hormonally induced activation of adenylate cyclase in homogenates prepared from developing human hearts.

The fluoride-sensitive, catalytic component of the enzyme was present at all gestational ages studied (5-17 weeks) and preceded the maturation of the hormone-sensitive, receptor component of adenylate cyclase. That the catalytic site of the enzyme is present during development before maturation of the receptor moiety, has been reported in a variety of tissues from several species $(4,7,13,22,24)$.

In the present study the activation of myocardial adenylate cyclase by catecholamines was shown to occur to a significant degree by $6-7$ weeks. The receptor retained characteristics of the $\beta$ type in that the NE-induced stimulation was readily antagonized by propranolol but not by phentolamine. Significant activation of adenylate cyclase by glucagon was observed by the 8 th -9 th fetal weeks. It is tempting to speculate that the catecholamine-sensitive receptor component of adenylate cyclase develops before the glucagon-sensitive element. This presumption is, however, tenuous, in that sufficient amounts of tissue could not be obtained at these earliest fetal ages in order to determine precisely the appearance of the myocardial receptor for glucagon. In addition, our preliminary data with only three samples do suggest that glucagon $\left(6 \times 10^{-7}, \mathrm{M}\right)$ may activate the receptor by $6-7$ weeks. This finding was not significant and clearly more studies with complete doseresponse relations are needed to clarify these observations. These findings do, however, lend further support to the hypothesis that perhaps these two classes of hormones activate adenylate cyclase via different receptors $(12,14,15,20,21)$. In preliminary studies with human fetal cardiac tissues stimulation of adenylate cyclase by glucagon and catecholamines was demonstrated at $12-13$ weeks of gestation $(3,19)$. Neither of these studies were carried out at an earlier stage of development. On the other hand, physiologic experiments conducted upon human myocardium revealed the presence of a functional $\beta$ receptor by the 8 th week (1). Our findings might be supported by animal studies in which the metabolically active, adrenergic-sensitive receptor component of adenylate cyclase developed at a considerably earlier stage in the rat and the mouse heart than did the glucagon-sensitive receptor (2, 27). Furthermore, Martin et al. (17) recently reported that an intact adenylate cyclase $\beta$ receptor developed before either innervation or catecholamine-induced actions on rat heart contractility. With respect to innervation of human fetal myocardium, our previous study (4) revealed the presence of small, intensely fluorescent (SIF) catecholamine cells in the adventitia of the aortic root by the 8 th fetal week. The function of these SIF cells is unclear. Adrenergic fibers were not seen in our study; however, Taylor (26) has observed preterminal adrenergic nerve fibers in the atrial epicardium of a $65-\mathrm{mm}$ human fetus of approximately 10 weeks of gestational age.

In the present investigation ine stimulation of adenylate cyclase by NE was somewhat diminished at the later fetal stages $(12-17$ weeks). We attribute our observations to the results of Mirkin and others (see review) (18), in that the responses of sympathetic receptors seem to vary during the course of development. In this regard it was shown that peak sensitivities of adenylate cyclase to histamine in the developing rabbit lung occurred before birth and at 20 days postpartum 
(22). Along these lines of reasoning it not known when the ATPase(s) become functional during human cardiac development. This diminished response at 12-17 weeks of fetal age could be caused either by ATPase or by phosphodiesterase, which has been shown to develop progressively from 10 through 15 weeks of human myocardial development (4).

Histamine readily activated myocardial adenylate cyclase by 6-7 weeks of gestation. Whether the histamine-sensitive receptor develops separately or at an earlier fetal age than the catecholamine-sensitive receptor was not borne out by the present investigation.

\section{CONCLUSION}

Receptor components of adenylate cyclase in the developing human heart were responsive to catecholamines and histamine by $6-7$ embryonic weeks of age. The receptor site of the enzyme that was sensitive to norepinephrine appeared to be of the $\beta$ type in that enzyme activation was readily blocked by propranolol but not phentolamine. The glucagon-sensitive moiety of adenylate cyclase was fully functional by $8-9$ fetal weeks and preliminary findings suggested an earlier development for enzymatic activation by the polypeptide hormone. The results indicate that a variety of hormones are capable of influencing human fetal myocardial receptors at an early stage of development.

\section{SUMMARY}

Human fetal hearts varying in age from 5-17 weeks were assayed for adenylate cyclase activity. Sodium fluoride activated the enzyme preparations at all developmental ages. Stimulation of adenylate cyclase by norepinephrine was detected at 6-7 weeks, whereas significant enzyme activation by glucagon was not evident until 8-9 weeks of gestational age. Other hormonal agents, namely, histamine, epinephrine, and isoproterenol, were readily active at 6-7 weeks of development. The $\alpha$-adrenergic blocking agent, phentolamine, was without significant actions upon either basal or norepinephrine-induced stimulation of adenylate cyclase. On the other hand, the $\beta$-adrenergic blocking agent, propranolol, antagonized enzyme stimulation by norepinephrine.

\section{REFERENCES AND NOTES}

1. Chang, T. D., and Cumming, G. R.: Chronotropic responses of human heart tissue cultures. Circ. Res., 30: 628 (1972).

2. Clark, C. M., Jr., Beatty, B., and Allen, D. O.: Evidence for delayed development of the glucagon receptor of adenylate cyclase in the fetal and neonatal rat heart. J. Clin. Invest., 52: 1018 (1973).

3. Coltart, D. J., Davis, G. M., Gillibrand, I. M., and Hames, J.: Adenyl cyclase activity in the developing human fetal heart. J. Physiol, 225: 38P (1972)

4. Dail, W. G., Jr., and Palmer, G. C.: Localization and correlation of catecholamine-containing cells with adenyl cyclase and phosphodiesterase activities in the human fetal heart. Anat. Rec., 177: 265 (1973).

5. Friedman, W., Sobel, B., and Cooper, C.: The age-dependent enhancement of cardiac contractility by glucagon: Relationship to activation of the adenyl cyclase enzyme. Pediat. Res., 3: 349 (1969).

6. Gardner, E., and Gray, D. J.: The prenatal development of the human femur. Amer. J. Anat. 129: 121 (1970).

7. Gengler, W. R. and Forte, L. R.: Neonatal development of rat kidney adenyl cyclase and phosphodiesterase. Biochim. Biophys. Actta, 279: 367 (1972).
8. Gilman, A. G.: A protein binding assay for adenosine $3^{\prime}: 5^{\prime}$-cyclic monophosphate. Proc. Nat. Acad. Sci. U. S. A., 67: 305 (1970).

9. Johnson, R. A., and Sutherland, E. W.: Detergent-dispersed adenylate cyclase from rat brain. J. Biol. Chem., 248: 5114 (1973).

10. Kebabian, J. W., Petzold, G. L., and Greengard, P.: Dopaminesensitive adenylate cyclase in caudate nucleus of rat brain and its similarity to the "dopamine receptor." Proc. Nat. Acad. Sci. U. S. A., 69: 2145 (1972).

11. Klainer, L. M., Chi, Y. M., Friedberg, S. L., Rall, T. W., and Sutherland, E. W.: Adenyl cyclase. IV. The effects of neurohormones on the formation of adenosine $3^{\prime}, 5^{\prime}$-phosphate by preparations from brain and other tissues, J. Biol. Chem., 237: 1239 (1962).

12. Klein, I., and Levey, G. S.: Activation of myocardial adenyl cyclase by histamine in guinea pig, cat and human heart. J. Clin. Invest., 50: 1012 (1971).

13. Kohrman, A. F.: Patterns of development of adenyl cyclase activity and morepinephrine responsiveness in the rat. Pediat. Res, 7: 575 (1973).

14. Kukovetz, W. R., Poch, G., and Wurm, A.: Effect of catecholamines, histamine and oxyfedrine on isotonic contraction and cyclic AMP in the Guinea-pig heart. Naunyn-Schmiedeberg's Arch. Pharmak, Exp. Pathol,, 278: 403 (1973).

15. Levey, G. S., and Epstein, S. E.: Myocardial adenyl cyclase: Activation by thyroid hormones and evidence for two adenyl cyclase systems. J. Clin. Invest. 48: 1903 (1969).

16. Lowry, O. H., Rosebrough, N. J., Farr, A. L., and Randall, R. J.: Protein measurement with the Folin phenol reagent. J. Biol. Chem., 193: 265 (1951).

17. Martin, S, Levey, B. A, and Levey, G, S. Development of the cardiac beta adrenergic receptor in the fetal rat heart. Biorhem. Biophys. Res. Commun., 54: 949 (1973).

18. Mirkin, B. L.: Ontogenesis of the adrenergic nervous system: functional and pharmacologic implications. Fed. Proc., 31: 65 (1972).

19. Menon, K. M. J., Giese, S., and Jaffe, R. B.: Hormone and fluoride-sensitive adenylate cyclases in human fetal tissues. Biochim. Biophys, Acta, 304: 203 (1973).

20. Murad, F., and Vaughan, M.: Effect of glucagon on rat heart adenyl cyclase. Biochem. Pharmacol., 18: 1053 (1969).

21. Nickerson, M.: Adrenergic receptors. Circ. Res., 23 (suppl. 1): 1 (1973).

22. Palmer, G. C.: Cyclic $3^{\prime}, 5^{\prime}$-adenosine monophosphate response in the rabbit lung-adult properties and development. Biochem. Pharmacol., 21: 2907 (1972).

23. Robison, G. A., Butcher, R. W., and Sutherland, E. W.: On the relation of hormone receptors to adenyl cyclase. In: J. F. Danielli, J. F. Moran, and D. J. Triggle: Fundamental Concepts in Drug-Receptor Interactions, p. 59 (Academic Press, New York, 1969).

24. Schmidt, M. J., Palmer, G. C., Dettbarn, W.-D., and Robinson, G. A.: Cyclic AMP and adenyl cyclase in the developing rat brain. Develop. Psychobiol., 3: 53 (1970).

25. Streeter, G. L.: Developmental horizons in human embryos. Description of age groups XV, XVI, XVII and XVIII. Contributions to Embryology. Carnegie Inst., Wash., $32: 133$ (1948).

26. Taylor, I. M.: Personal communication.

27. VonHungen, K., and Roberts, S.: Adenylate-cyclase receptors for adrenergic neurotransmitters in rat cerebral cortex. Eur. J. Biochem., 36: 391 (1973).

28. Wildenthal, K., and Wakeland, J. R.: Maturation of responsiveness to cardioactive drugs, differential effects of acetylcholine, norepinephrine, theophylline, tyramine, glucagon and dibutyryl yclic AMP on atrial rate in hearts of fetal mice. J. Clin. Invest., 52: 2250 (1973).

29. Sigma Chemical Co., St. Louis, Mo.

30. Ciba Pharmaceuticals.

31. Ayerst Laboratories.

32. Calbiochem, Los Angeles, Calif,

33. The authors are indebted to Dr. L. Koplik for help in these investigations.

34. This work was supported by a Dan Burrows Memorial Grant awarded by the New Mexico Heart Association, and MH-21584.

35. Requests for reprints should be addressed to: G. Palmer, M.D., Department Pharmacology, University of New Mexico School of Medicine, Albuquerque, N. M. 87131 (USA).

36. Accepted for publication September 20, 1974. 